\title{
Low voltage electrocardiogram after acute myocardial infarction
}

\author{
K. M. Fox, I. W. Tomlinson, D. R. Meek, R. W. Portal, and Clive P. Aber \\ From the Department of Cardiology, Kingston General Hospital, and Hull Royal Infirmary, Hull
}

In a retrospective study of patients with acute myocardial infarction admitted to a coronary monitoring unit in 1971 I2 per cent (39 patients) had low voltage electrocardiograms within 72 hours of admission. Of these, 7 patients $(18 \%)$ died while in hospital and a further $9(23 \%)$ died within one year of their infarction. Of the 23 patients who survived, 16 were severely incapacitated by their symptoms at the one-year follow-up.

$A$ low voltage electrocardiogram in association with acute myocardial infarction appears to imply a poor prognosis in terms of both mortality and morbidity, independently of other prognostic indices.

The prognostic significance of the low voltage electrocardiogram in association with acute myocardial infarction has not been clearly established. Theoretical considerations and clinical experience suggest a relatively poor outlook in this group of patients who may well have widespread myocardial damage. The present study was, therefore, designed to examine the significance of this type of electrocardiographic pattern in acute myocardial infarction.

\section{Patients and methods}

The case notes of all patients with proven myocardial infarction admitted to the Coronary Monitoring Unit at Kingston General Hospital, Hull, during 1971 were studied. Of 329 patients 39 (12\%) had a low voltage electrocardiogram in one or more records within 72 hours of admission, not attributable to other recognized causes (Willius and Killins, 1927).

Conventional 12-lead electrocardiograms were performed on the first 3 days after admission and thereafter weekly while the patients were in hospital unless there was an indication for obtaining further records.

A low voltage electrocardiogram was defined as a QRS deflection of less than $0.5 \mathrm{mV}$ in all of the standard and augmented limb leads. Records were all standardized at $\mathrm{I} \mathrm{cm}$ deflection corresponding to $\mathrm{I} \mathrm{mV}$ (Sprague and White, 1926; Willius and Killins, 1927).

Patients were followed up for a minimum period of 18 months and further electrocardiograms were obtained at each outpatient visit. Where a patient died outside hospital the cause of death was taken as that given on the death certificate or that provided by a coroner's post-

Received 4 October 1974. mortem report. Adequate follow-up data were available on all patients.

Serum aspartate aminotransferase levels were estimated daily for the first three days and then weekly using a modified spectrophotometric method with a reaction rate analyser. The upper limit of normal for our laboratory was 22 i.u. Serum aspartate aminotransferase levels were considered abnormal if they were ro per cent above the laboratory's upper limit of the normal range.

The diagnosis of anterior and inferior myocardial infarction was based on the electrocardiographic criteria of the World Health Organization (1959). The recommendations of Perloff were used to define 'true' posterior infarction (Perloff, 1964) but none was observed. In two patients the site of infarction was obscured by pre-existing electrocardiographic abnormalities, and a diagnosis of recent infarction was made on a characteristic history, high peak serum aspartate aminotransferase levels (37 and 160 i.u., respectively), and typical temperature curves.

The patients' progress was considered 'unsatisfactory' at follow-up if there were dyspnoea on moderate exertion (grade IIb or more) and/or angina pectoris sufficient to cause considerable limitation of the patient's normal daily activities. All patients who fell into this category were unable, because of their symptoms, to return to their previous occupation. Patients who had returned to their previous occupation or who continued with their normal daily activities were considered to have made 'satisfactory' progress.

Left heart failure was defined as radiological pulmonary oedema. Lesser degrees of pulmonary congestion were excluded, as observer error in this situation is high.

Major arrhythmias included ventricular tachycardia, ventricular fibrillation, asystole, and complete heart block. 
TABLE I Clinical data of 39 patients with low voltage electrocardiograms after myocardial infarction

\begin{tabular}{|c|c|c|c|c|c|c|c|c|c|c|}
\hline \multirow[t]{2}{*}{ Groupt } & \multirow{2}{*}{$\begin{array}{l}\text { No. of } \\
\text { patients }\end{array}$} & \multicolumn{2}{|l|}{$\operatorname{Sex}$} & \multicolumn{2}{|c|}{$A g e(y r)$} & \multicolumn{2}{|c|}{ Past medical history } & \multicolumn{2}{|c|}{ Site of recent infarction } & \multirow[b]{2}{*}{ Uncertain $\star$} \\
\hline & & Male & Female & $45-65$ & $>65$ & Angina & Infarcts & Anterior & Inferior & \\
\hline $\mathbf{I}$ & 7 & 6 & $\mathbf{I}$ & 6 & $\mathbf{I}$ & 4 & 2 & 5 & 2 & 一 \\
\hline 2 & 9 & 7 & 2 & 7 & 2 & 5 & 3 & 7 & $\mathbf{I}$ & $\mathbf{I}$ \\
\hline 3 & 16 & 13 & 3 & 8 & 8 & 6 & 5 & 5 & Io & $\mathbf{I}$ \\
\hline 4 & 7 & 7 & 一 & 5 & 2 & 2 & - & 4 & 3 & - \\
\hline Total & 39 & 33 & 6 & 26 & 13 & 17 & 10 & 21 & 16 & 2 \\
\hline
\end{tabular}

* True posterior infarction was not observed.

$\dagger$ As defined in text.

\section{Results}

The clinical details of the 39 patients with low voltage electrocardiograms are shown in Table $I$. They formed four groups according to their subsequent progress.

\section{Group I: early deaths}

Seven patients (18\%) died in hospital within two months of their admission. A necropsy was performed on 5 patients in this group. Widespread coronary artery disease was found in every case and in none was a pericardial effusion seen.

\section{Group 2: late deaths}

Of the 32 patients who survived their initial hospital admission, $9(28 \%)$ died within the 12 months following their infarction. The cause of death was invariably a consequence of their ischaemic heart disease.

\section{Group 3: unsatisfactory progress}

Of the original 39 patients, $23(59 \%)$ survived the first 12 months but $16(70 \%)$ of them failed to make a satisfactory recovery: 5 had moderately severe angina, 6 had significant dyspnoea (grade IIb or more), and a further 5 had both angina and dyspnoea. Of the 8 patients (all under the age of 65) who were employed before admission, 7 were forced to retire prematurely and one could only work in a supervisory capacity.

\section{Group 4: satisfactory progress}

There were only 7 (18\%) patients in this group.

The overall survival curve is presented in Fig. I. At 12 months, $23(59 \%)$, and at 18 months, 21 (54\%) patients were still alive.

In view of these findings the series was examined to see if this high morbidity and mortality, particularly in the first year after discharge, could have been predicted using other prognostic criteria.

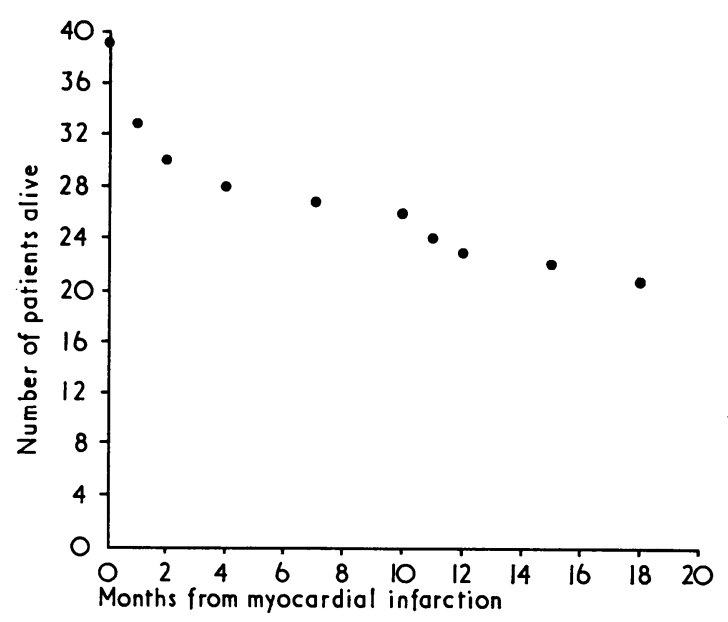

FIG. I Survival after myocardial infarction.

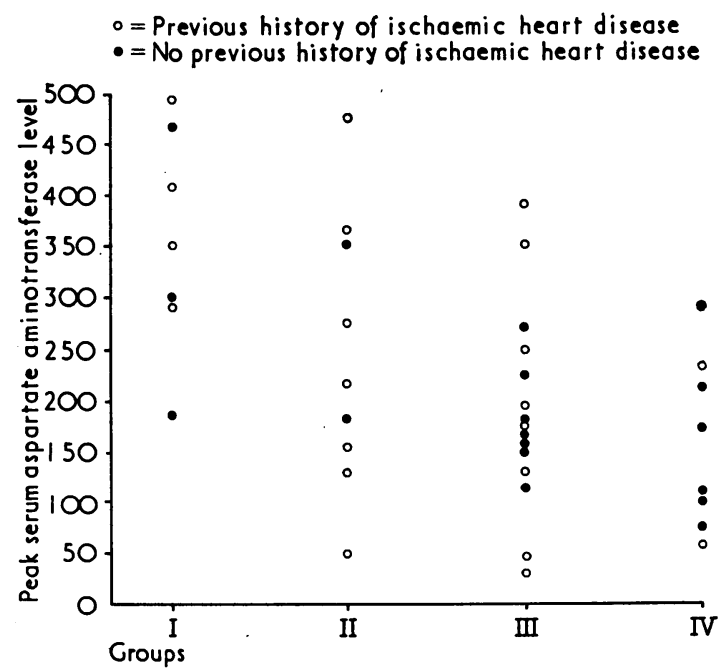

FIG. 2 Peak serum aspartate aminotransferase levels for each patient classified according to group, as defined in the text. 
TABLE 2 Complications of 39 patients with low voltage electrocardiograms after myocardial infarction

\begin{tabular}{lccll}
\hline Group & $\begin{array}{l}\text { No. of } \\
\text { patients }\end{array}$ & $\begin{array}{l}\text { Left } \\
\text { ventricular } \\
\text { failure }\end{array}$ & $\begin{array}{l}\text { Major } \\
\text { arrhythmias }\end{array}$ & $\begin{array}{l}\text { Increased } \\
\text { cardiothoracic } \\
\text { ratio }>\text { 50 per cent }\end{array}$ \\
\hline I & 7 & 4 & 7 & 3 \\
2 & 9 & 3 & 3 & 2 \\
3 & 16 & 3 & 2 & 4 \\
4 & 7 & 2 & -12 & 1 \\
Total & 39 & 12 & 12 & 10 \\
\hline
\end{tabular}

* As defined in text.

This appears to be the case as the mean peak serum aspartate aminotransferase level fell sequentially from group I to group 4 (Fig. 2). Similarly, the incidence of major arrhythmias, left ventricular failure, and increased cardiothoracic ratio was highest in group $\mathrm{I}$ and lowest in group 4 (Table 2).

The patients with a persistently low voltage electrocardiogram had the same prognosis as those in whom the electrocardiographic voltage subsequently showed a maximum deflection of more than $0.5 \mathrm{mV}$ on one or more occasions in the ward or at outpatient follow-up. There were only 3 patients in whom a single low voltage electrocardiogram was obtained. All 3 patients died within 48 hours of admission.

\section{Discussion}

Low voltage electrocardiograms are known to be associated with diffuse myocardial damage, pericardial and endocrine disorders, emphysema, and obesity. Isolated examples of this electrocardiographic pattern have been recorded in other conditions (Willius and Killins, 1927; Oppenheimer and Mann, 1923; Thacher and White, 1926).

Wearn (1923) drew attention to the high incidence of diminished voltage in the electrocardiograms of patients dying from coronary occlusion. Similar observations were made by Barnes (1935), who considered low voltage a poor prognostic feature in patients with myocardial infarction. In contrast, Rosenbaum and Levine (194I) demonstrated a relatively good prognosis in patients with low voltage electrocardiograms who had survived their first infarct. Katz, Mills, and Cisneros (1949) found an increased mortality in the first two months after myocardial infarction in patients with low voltage electrocardiograms, but in those who survived longer this electrocardiographic pattern appeared to be of no prognostic value, a finding confirmed by others (Cole, Singian, and Katz, 1954; Kaplan and Berkson,
1964; Shanoff et al., 1966; Coronary Drug Project Research Group, 1972). These apparent prognostic discrepancies may be because in some of these studies 'low voltage' was not adequately defined.

The low voltage electrocardiogram after myocardial infarction may be associated with poor myocardial performance as a result of widespread myocardial damage, such as can also occur in amyloidosis, myxoedema, and the late stages of congestive cardiomyopathy. This concept is substantiated in group I (early deaths) where widespread coronary artery disease was found at necropsy, but in the other group, this remains speculative as necropsy data were lacking. However, if this supposition is correct, a poor long-term prognosis would be expected. In keeping with this the initial hospital mortality was 18 per cent, which is only slightly greater than the figure for our unit as a whole (13\% mortality - Aber, 1973), whereas the mortality at one year had risen to 4I per cent which is far higher than anticipated (Norris et al., 1970). Similarly, the morbidity at one-year follow-up was appreciably higher than expected (Royston, 1972), for of the original 39 patients only $7(18 \%)$ were free from incapacitating symptoms. Why these patients were relatively well at 18 months is not clear, since there appeared to be no significant difference between this group and the other three groups when assessed by other prognostic features.

Patients in whom the serum aspartate aminotransferase was very high (greater than 250 i.u.) had a high morbidity and mortality, as would be expected (Chapman, 1972; Chapman and Gray, 1973). In these patients the presence of a low voltage electrocardiogram is of little additional value. However, in 20 of our patients the serum aspartate aminotransferase was only moderately up (less than 200 i.u.), yet 75 per cent were severely incapacitated or dead at the end of one year. This mortality and morbidity is considerably greater than would be generally anticipated from the height of the peak serum aspartate amino- 
transferase alone. Similarly, if other prognostic indices had been used, such as a past history of ischaemic heart disease, the occurrence of ventricular failure, or serious arrhythmia and a cardiothoracic ratio of more than 50 per cent (Norris et al., 1969; Peel et al., 1962) a better outlook would have been expected. It is this group of patients (with a low voltage electrocardiogram and relatively low peak serum aspartate aminotransferase), or where myocardial enzyme levels are not available, that the finding of a low voltage electrocardiogram could have particular prognostic value.

\section{References}

Aber, C. (1973). Coronary care. In Recent Advances in Cardio$\log y$, 6th ed., p. 84. Ed. by J. Hamer. Churchill Livingstone, London.

Barnes, A. R. (1935). Electrocardiogram in myocardial infarction. Review of one hundred and seven clinical cases and one hundred and eight cases proved at necropsy. Archives of Internal Medicine, 55, 457.

Chapman, B. L. (1972). Relation of cardiac complications to SGOT level in acute myocardial infarction. British Heart fournal, 34, 890.

Chapman, B. L., and Gray, C. H. (1973). Prognostic index for myocardial infarction treated in a coronary care unit. British Heart fournal, 35, 135.

Cole, D. R., Singian, E. B., and Katz, L. N. (1954). The longterm prognosis following myocardial infarction and some factors which affect it. Circulation, 9, 321 .

Coronary Drug Project Research Group (1972). The prognostic importance of the electrocardiogram after myocardial infarction. Annals of Internal Medicine, 77, 677.

Kaplan, B. M., and Berkson, D. M. (1964). Serial electrocardiograms after myocardial infarction. Annals of Internal Medicine, 60, 430.

Katz, L. N., Mills, G. Y., and Cisneros, F. (1949). Survival after recent myocardial infarction. Archives of Internal Medicine, 84, 305 .

Norris, R. M., Brandt, P. W. D., Caughey, D. E., Lee, A. J., and Scott, P. J. (1969). A new coronary prognostic index. Lancet, I, 274.

Norris, R. M., Caughey, D. E., Deeming, L. W., Mercer,
C. J., and Scott, P. J. (1970). Coronary prognostic index for predicting survival after recovery from acute myocardial infarction. Lancet, 2, 485.

Oppenheimer, B. S., and Mann, H. (1923). An electrocardiographic sign in pericardial effusion. Proceedings of the Society for Experimental Biology and Medicine, 20, $43 \mathrm{I}$.

Peel, A. A. F., Semple, T., Wang, I., Lancaster, W. M., and Dall, J. L. G. (1962). A coronary prognostic index for grading the severity of infarction. British Heart fournal, 24,745 .

Perloff, J. K. (1964). The recognition of strictly posterior myocardial infarction by conventional scalar electrocardiography. Circulation, 30, 706.

Rosenbaum, F. F., and Levine, S. A. (I94I). Prognostic value of various clinical and electrocardiographic features of acute myocardial infarction. I. Immediate prognosis. Archives of Internal Medicine, 68, 913.

Royston, G. R. (1972). Short stay hospital treatment and rapid rehabilitation of cases of myocardial infarction in a district hospital. British Heart fournal, 34, 526.

Shanoff, H. M., Little, J. A., Csima, A., and Yano, R. (1966). Studies of male survivors of myocardial infarction. VIII. The electrocardiogram and ten-year survival. American fournal of Cardiology, 18, 535 .

Sprague, H. B., and White, P. D. (1926). The significance of electrocardiograms of low voltage. Fournal of Clinical Investigation, 3, 109.

Thacher, C., and White, P. D. (1926). The electrocardiogram in myxedema. American fournal of the Medical Sciences, 171, 6r.

Wearn, J. T. (1923). Thrombosis of the coronary arteries with infarction of the heart. American fournal of the Medical Sciences, 165, 250.

Willius, F. A., and Killins, W. A. (1927). The occurrence and significance of electrocardiograms of low voltage. Archives of Internal Medicine, 40, 332.

World Health Organization (1959). Hypertension and coronary heart disease: classification and criteria for epidemiological studies. First report of the expert committee on cardiovascular diseases and hypertension. World Health Organization, Geneva, Technical Report Series, No. 168.

Requests for reprints to Dr. Clive P. Aber, Cardiac Department, Kingston General Hospital, Hull $\mathrm{HU}_{3}$ IUR. 